\section{Unrestrained outsourcing in Brazil: more precarization and health risks for workers}

\author{
A terceirização sem limites: mais precarização e \\ riscos de morte aos trabalhadores
La tercerización sin límites: más precarización y riesgos de muerte para los trabajadores

Graça Druck 1

\begin{abstract}
This article discusses the current status of outsourcing in Brazil, with new regulation underway featuring a bill of law under review by the National Congress, aimed at allowing outsourcing for all activities. The authors argue that outsourcing and precarization of work are inseparable phenomena, based on the results of 20 years of research in Brazil that reveals the more precarious working conditions of outsourced workers in different occupational categories. They focus particularly on workers' health: outsourcing of risks has led to more fatal work accidents, invariably at higher rates in outsourced workers. Finally, the article contends that to remove restraints on outsourcing in Brazil amounts to legalizing and legitimizing predatory workforce exploitation, disregarding workers' physical limits, exposing them to risk of fatal accidents, and reverting to forms of work that violate the human condition.
\end{abstract}

Outsourced Services; Working Conditions; Occupational Health

$\begin{array}{ll}1 \text { Universidade Federal da } & \text { Correspondence } \\ \text { Bahia, Salvador, Brasil. } & \text { G. Druck } \\ & \text { Rua Aristides Novis 190, } \\ & \text { Salvador, BA 40210-909, } \\ & \text { Brasil. } \\ & \text { druckg@gmail.com }\end{array}$




\section{Introduction}

This article discusses the current status of outsourcing in Brazil, marked by a heated clash between workers' organizations and businesses and focusing on a proposal for new regulation of outsourcing through a bill of law under review in the Brazilian National Congress that allows outsourcing of all business activities. In addition, a recent ruling by the Brazilian Supreme Court impacts the possibilities for the expansion of outsourcing in the public sector.

The article will present evidence of an outsourcing epidemic in Brazil and its effects on working conditions and health, with a discussion of indicators attesting to the inseparability of outsourcing and precarization of work in different occupational groups. The analysis highlights the relationship between outsourcing and workers' health, presenting a summary of the research on outsourcing and accidents in different occupational categories (the results of which show deterioration in this relationship), besides addressing specific information from recent years. The data sources were articles, theses, books, and research reports by scholars and academic institutions, trade unions, and business associations.

\section{Current status of outsourcing in Brazil and proposed new regulation: Bill of Law 4,330}

The outsourcing phenomenon is neither new nor old in Brazil or the world. This form of work organization and management has its roots in the industrial revolution. However, in the history of work it was essentially transformed and redefined. In the last 40 years, outsourcing has been incorporated into productive restructuring processes, with Japanese Toyotism as its main inspiration. As this pattern of work organization Westernized, contracting out or outsourcing has occupied a central place. Together with globalization of capital, outsourcing became capital's favorite and most efficient way to flexibilize labor, as a symbol of entrepreneurial modernity and the new basis for global competitiveness.

In Brazil, the old phenomenon of outsourcing had its roots in farm work, with the "straw cat" system or intermediation in the hiring of seasonal workers (flexible according to harvest seasons). During Brazil's early urban industrial development, with the installation of factories, outsourcing occupied a secondary position. However, with the rise of durable goods factories (e.g., the automobile industry), outsourcing became part of the productive structure and began to spread.
Outsourcing only really became a new phenomenon in Brazil as part of "flexible accumulation" in the context of productive restructuring, with the phenomenon of economic and financial globalization and neoliberal policies starting in the early 1990s. The novelty lies in outsourcing's central position and amplitude in all activities. Outsourcing is no longer peripheral, but has become a key practice in all types of companies: in industry, public and private services, and commerce, i.e., in all types of work.

Research on outsourcing in the last 20 years indicates exponential growth in all sectors. Studies in the early 1990s focused mostly on the automobile, chemical, petrochemical, and petroleum industries. The results already presaged the trend that was confirmed in the following decade, as attested by the first large study of the petrochemical complex in Bahia State, Brazil, in 1993 1. The analyses found a growth in outsourcing concurrent with a drop in the number of direct company employees, indicating qualitative changes with outsourcing in core areas, revealing a process of "quadruple" precarization: of work, health, employment, and trade union organization 2,3,4.

As for legislation and regulation of outsourcing in Brazil, according to studies by experts, Law $6,019 / 1974$ authorizing the outsourcing of services in private security and transportation of cash and valuables by financial institutions helped legitimize a practice that was already commonplace in the services market. Previous regulation was based on Law 5,645/1970, which applied only to the public sector and authorized contracting out of services in transportation, maintenance, custody, securities operations, cleaning, and similar activities. The law prohibited outsourcing of any permanent company activities. Under this regulation, Brazilian Superior Labor Court (TST) issued Ordinance 256 in 1986 which banned intermediary companies from hiring workers except for temporary work and surveillance services 5 . In 1993, pressured by private business, the TST flexibilized Ordinance 256, acknowledging the legality of hiring any services related to the company's intermediate activities and issuing Ordinance 331, which overruled 256 and permitted (without characterizing an employment relationship) the hiring of services in surveillance, cleaning, and maintenance, as well as specialized services related to the hirer's intermediate activity.

This change had immediate repercussions on services by flexibilizing the limits on outsourcing and allowing it in the companies' permanent activities. The difference was now between ancillary (non-core) activities and core activities, leading to an endless technical and legal debate on the nature of activities, namely ancillary or pe- 
ripheral activities versus core activities. Although Ordinance 331 was amended, its two essential provisions were maintained: the ban on outsourcing core activities and the hiring company's joint liability.

In practice, companies outsource a large share or even the majority of jobs by adopting Ordinance 331 as a shield to argue that they "only" outsource non-core activities. Given the countless cases of defaults by outsourced companies and illnesses and deaths of outsourced workers, the hiring company is in a comfortable position, without assuming any responsibility, since liability falls on the third party, which is tried. Even so, there was a limit that provided the grounds for rulings by the Brazilian Labor Court System: the ban on outsourcing core activities. Still, this limit did not prevent the expansion of outsourcing, thus shaping a veritable epidemic that developed in the 1990s and continues unabated in the 2000s 6 .

This outsourcing epidemic in Brazil culminated in Bill of Law 4,330/2004, drafted and submitted by then-National Congressman and businessman Sandro Mabel. The bill aims primarily to eliminate any and all limits on outsourcing, that is, to allow it for all company activities, including contracting-out networks, pejotização (a neologism from the Portuguese acronym PJ, or Inc., in which company employees form their own individual micro-businesses), and denying the full joint and several liability of the hiring parties. The various attempts to bring the bill up for vote in Congress met with organized resistance from trade unions, labor jurists, researchers, labor law institutions, and even 19 of the 26 justices of the TST, who published a letter in 2013 rebuffing Bill of Law 4,330 with the following, among other considerations:

"II. The provision in Bill of Law 4,330-A/2004 that allows outsourcing all across the economy and society is bound to seriously jeopardize social, labor, and social security rights in the country, with the potential to provoke mass migration of millions of workers now hired under full contracts by companies and institutions towards a new situation as outsourced workers, sparking a severe cutback in wages and labor and social rights and safeguards.

$$
\text { (...) }
$$

VI. The generalization and deepening of labor outsourcing encouraged by the Bill of Law in question will also cause an additional and significant overload on the Unified Health System (SUS), already heavily strained. Outsourced workers are victims of much higher rates of work accidents and occupational/professional diseases than the direct employees of the companies that use services. If Bill of Law 4,330-A/2004 passes, the resulting boom in outsourcing will automatically multiply the demands on the Brazilian Unified National Health System (SUS) and the Social Security System (INSS)" (Letter to Congressman Décio Lima, Chairman of the House Committee on Constitution and Justice and Citizenship, August 27, 2013, authors' emphasis).

Bill 4,330 came up for vote in the House of Representatives in April 2015 without any prior discussion on the floor, using a regimental provision that gives dictatorial powers to Speaker Eduardo Cunha, who has systematically used and abused this power to force votes on controversial bills that radically alter life in society, completely disregarding any democratic review. The response has been a broad national mobilization coordinated by the main trade union confederations and social movements, with strikes and street demonstrations, and by social network, which managed to change the first vote (324 to 137) but was unable to prevent the bill from passing by a narrow margin of 230 to 203 votes in the House of Representatives.

However, a permanent campaign by trade unions and various other class institutions had a different impact in the Senate, where the bill was subsequently submitted (and where it is called Bill of Law 30). The Senate established a different procedure by organizing public hearings in Brazil's states and forming thematic committees; that is, there is no deadline for voting on the bill, and several Senators have already spoken out publicly against it. If the bill passes in the Senate, it will be referred to President Dilma Roussef, who has veto power.

During this same period, in which attention focused on the National Congress, the Brazilian Supreme Court issued its ruling on April 15, 2015, concerning a Direct Claim of Unconstitutionality filed in 1998 against the law enacted by the Fernando Henrique Cardoso Administration, according to which the government can hire social organizations to provide services in the areas of health, education, culture, sports and leisure, science and technology, and environment. This amounts to outsourcing mediated by so-called social organizations (foundations, NGOs, cooperatives, etc.) in the core activities of public service. The Supreme Court ruled in favor of the constitutionality of outsourcing in all these sectors. It was a victory for the neoliberal concept of the state that transfers public funds to these private organizations, who are free to hire workers without public admissions or bidding, and which means the gradual demise of public service and the civil service career, the social role of which is essential in a democratic state 2 . 


\section{Outsourcing and precarization: some indicators}

Data from throughout Brazil invariably identify a direct association between outsourcing and precarization of work, essentially one and the same phenomenon. The sources include qualitative case studies and quantitative studies based on government, trade union, and labor law statistics (Office of the Public Prosecutor for Labor, tax auditors, and labor court judges). This situation has persisted for the last 20 years. Therefore, the studies are not about the future, after enforcement of a law that allows outsourcing for all economic activities. The studies are not meant to make forecasts or wager on what might happen from here on, as the defenders of outsourcing contend. The studies provide results about what has actually taken place in Brazil with the enforcement of Ordinance 331, which prohibits outsourcing of core activities but does not prevent creating first and second category workers in a situation of disregard for human dignity and the dignity of work, setting them apart as unequal working men and women. Outsourcing is the most common way for companies to avoid labor legislation and disrespect the rights established by the Brazilian Labor Code (CLT), generating social and political vulnerability and jeopardizing the employment relationship as a basic element of formal contracts.

Outsourcing is not only the main way to flexibilize labor, but also the principal tool for economic, social, and political precarization, which has been the center of the dynamics of so-called flexible capitalism or flexible accumulation in times of financial capital's hegemony. Volatility in the movement of this type of capital has led to volatile use of the workforce, reaffirming the latter's nature as merchandise whose provisional disposability - through unemployment and precarious contracts - or definitive expansion of fatal accidents becomes central and strategic to capital.

Based on a so-called "typology of precarization”, expressed as a multifaceted phenomenon 3,4 , we present some indicators of outsourcing in Brazil with paradigmatic evidence of this precarization in all its dimensions. Outsourcing appears as the principal phenomenon that demonstrates each of these types or dimensions of precarization:

(1) Workforce commodification, producing a heterogeneous and segmented labor market marked by structural vulnerability and precarious forms of insertion and contracts, without social protection, where outsourcing serves as an indicator of this process;
(2) Work management and organization standards leading to extremely precarious conditions through the intensification of work with the imposition of unachievable targets, extended workdays, multitasking, etc., sustained by fearbased management, abuse of power, moral harassment, and the discrimination created by outsourcing. Outsourced workers suffer the worst working conditions, as indicated above;

(3) Unsafe and unhealthy working conditions resulting from management standards that disregard necessary training, information on risks, collective preventive measures, etc., in the search for increased productivity at any cost (including human lives), leading to high work accident and illness rates, a highly typical situation in outsourced workers, whose accident rates consistently exceed those of direct company employees; (4) Unemployment or constant threat of losing one's job. Isolation, loss of rootedness, bonds, and integration, and a collective identity perspective resulting from disposability, devaluation, and exclusion are conditions with a decisively negative impact on class solidarity, undermining it with the brutal competition triggered among workers themselves; the phenomena are especially present among outsourced workers and in their relationship to other workers;

(5) Weakening of trade union organization and workers' struggle and representation, resulting from fierce inter-worker competition, heterogeneity and division, leading to the fragmentation of trade unions, created mainly by outsourcing; (6) The condemnation and denial of Labor Law as the result of market fetishism, which has orchestrated and proclaimed the "crisis of labor law", questioning its tradition and existence as expressed in the forms of regulation by the state, whose labor and social laws have been violently condemned by neoliberal principles in defense of flexibilization as an inexorable process of modernity in the age of globalization. All these elements are summarized in Bill 4,330, which jurists have described as a direct assault on Brazil's CLT and related labor legislation.

The following information is not standardized, but comes from diverse sources and methodologies; however, it allows listing the followings indicators: (a) the ratio of outsourced workers to direct company employees; (b) wage differences between outsourced workers and company employees; (c) benefits not received by outsourced workers or received at lower values when compared to company employees; (d) denial of rights guaranteed by Brazil's CLT; (e) job turnover (time on the job for outsourced workers versus company employees); (f) workweek, or hours/week in the two groups; (g) fragmented trade union 
representation; and (h) workers' health, or number of work accidents and illnesses in outsourced workers versus company employees. These indicators were found in the following occupational categories: petrochemical, petroleum, metallurgical, construction, electricity, banking, telemarketing, and public service (outsourced workers in a government university). We also present the information on workers employed in outsourced or typically outsourceable services, which aggregates data on various professional categories.

When one analyzes the relationship between the numbers of outsourced workers and company employees, some occupational categories show a very high proportion of outsourced workers, exceeding the proportion of company employees. This is true in the petroleum industry, according to data presented by Coutinho 7 , where the number of outsourced workers was $418 \%$ that of company employees (or a ratio of 4.2 to 1 ). According to the COGE Foundation 8 , the ratio is 1.35 to one in the Brazilian electricity industry. According to data from the Yearbook of the Brazilian Chemical Industry, the ratio varies between 0.35 to one and 5.71 to one in some petrochemical companies. In other sectors the ratio is 0.84 to one, as in the case of bank workers, according to data presented by Sanches ${ }^{9}$ and considering only non-bank related financial services workers as outsourced workers. According to a survey at the Federal University of Bahia, the number of outsourced workers was $64 \%$ of the number of technical and administrative public servants. The number of workers in typically outsourced services as a whole was $36 \%$ that of employees in activities that typically hire directly, according to data from the Inter-Trade Union Department of Statistics of the Single Trade Union Confederation (CUT-DIEESE) 10.

Data on the time trend in this relationship show an exponential growth in the number of outsourced workers compared to company employees, with a tendency to invert the ratio between company employees and outsourced workers, as in the case of petroleum, electricity, and petrochemical workers.

The number of outsourced workers in the petroleum industry increased by $631.8 \%$ from 2000 to 2013 , compared to $121 \%$ for company employees. In the electricity industry, outsourced workers increased by 199\% from 2003 to 2012, compared to only $11 \%$ for company employees. In the petrochemical industry, outsourced workers outnumbered company employees in 2009-2012 in 6 of the 10 companies that provided data, reaching high percentage differences (128\% to $15 \%$, $157 \%$ to $43 \%$, and $102 \%$ to $15 \%$ ). Importantly, all this happened when Bill 4,330 was not in force, that is, when unlimited outsourcing was still not allowed.

The second indicator refers to wage differences. In the petrochemical industry, outsourced workers on average earned $52 \%$ as much as company employees, varying according to different jobs, from $27 \%$ to $87 \%$. In the petroleum industry, outsourced workers' on average earned $46 \%$ as much as Petrobras employees. Among bank workers, telemarketing workers earned $44 \%$ as much as bank employees 9 . For workers in typically outsourceable services, wages are $24.7 \%$ lower than for direct company employees.

In all occupational categories analyzed, outsourced workers receive either no profit share at all or a fixed, quasi-symbolic share, receive no transportation, daycare, or educational benefits, receive meal vouchers invariably lower than for direct employees, and have no right to company transportation. Overtime pay for outsourced workers is less than overtime pay obtained through collective bargaining in the case of petrochemical, petroleum, and bank workers.

The denial of rights provided by the CLT also has a huge negative impact, especially in the case of petrochemical and petroleum workers and public servants. Basic rights established for employees with signed work booklets are systematically disrespected, for example wage delays, failure to deposit the Government Severance Indemnity Fund for Workers (FGTS), delays in Christmas bonus, no vacation leave, and lack of Internal Accident Prevention Committees (CIPAs). Among outsourced workers in public service, a case study in a federal university found workers that had not taken a paid vacation for ten years, since there is a turnover of outsourced companies that fail to honor the work contracts and disappear, only to be replaced by others of the same stripe, a situation in which the employees never complete a full year on the job and thus cannot take vacations 11 .

As for the workweek, aggregate data for workers in typically outsourceable services show that they work three hours longer per week than other workers. In the case of bank workers the difference is much larger, reaching as much as 9 hours more per week (31 hours for direct bank employees and 40 hours for non-bank financial services workers).

As for time on the job at the company, turnover rates for all workers in Brazil are among the highest in the world. For outsourced workers in typically outsourceable sectors, average total time on the job is 2 years and 7 months (compared to 5 years and 8 months for other workers). The banking and financial services sector has a high turnover rate: $43 \%$ of non-bank financial 
services workers stay one year or less, as compared to only $19 \%$ among direct bank employees, according to data from CUT-DIEESE 10.

All of the above information represents the situation for work relations and working conditions for outsourced workers compared to company employees. All the indicators show sharp inequality: outsourced workers earn less, work longer, enjoy fewer rights and benefits, have less job stability, and are increasing more numerically than company employees. In short, in the context of social precarization of work affecting everyone, outsource workers suffer worse conditions than others, with serious implications for policy, collective bargaining and trade union organization, and workers' health.

In the area of trade union representation, the hypotheses debated in studies on outsourcing are confirmed: trade union pulverization, workers' fragmentation, weakening of collective bargaining, and perverse clashes among trade unions themselves, with four to six large trade unions within the same occupational category, as in the case of petrochemical, petroleum, and bank workers and public servants.

\section{Precarization of workers' health and living conditions}

Studies in the field of workers' health conclusively demonstrate the close relationship between working conditions and the health and disease process. Work organization and work processes determine health risks and problems. Companies' choices and decisions in the use of technologies, length of the workday, production intensity and pace, control of workers during the work process, accident prevention policies, employees' medical care, and work management policies are increasingly determined by outsourcing, with direct implications for workers' health.

All the above-mentioned indicators for outsourced workers characterize highly precarious working conditions. The addition of information on increased vulnerability due to exposure to risks and accidents when compared to company employees reveals an extremely perverse reality and serious social irresponsibility. Statistics confirm the existence of first and second-rate workers, a kind of discrimination that has led to deaths and mutilations as regular events among different occupational categories.

Thus, outsourced workers not only earn less, work longer, and enjoy less job stability and fewer rights, but they also suffer more work accidents, including fatal ones. Their health vulnerability and increased exposure to risks result precisely from their precarious work conditions and lack of adequate training, qualification, or protection through health and safety policies (generally lacking in outsourced companies) or CIPAs. To further aggravate this situation, recent studies in the industrial sector show that companies have outsourced their medical services. For example, in the petrochemical industry in Bahia State, Brazil, a survey in 2003 showed that $74 \%$ of companies outsourced the workers' medical service, purportedly responsible for monitoring workers' health through pre-employment medical examinations, periodic examinations, dismissal medical examinations, periodic control of risk exposure, and outpatient and accident care 12 .

In addition, when an accident occurs on the core company's premises (the situation for most outsourced workers in different branches of activity), a perverse clash over company liability often ensues. Work accidents are commonly not reported with Work Accident Notifications (CAT), or they may only be reported after visits by labor inspectors, complaints filed by trade unions, or press coverage of the accident.

Brazil has witnessed notorious difficulty in access to information on work accidents in the country. Official statistics have expanded the gathering of information on unreported accidents, but they still depend essentially on company records (CATs), which enjoy only partial compliance, particularly in outsourced companies, leading to underreporting of the total number of accidents in the country.

In the following sections, the available data on fatal work accidents refer exclusively to outsourced workers hired in compliance with the CLT. Three major sectors of activities stand out, namely the petroleum, electricity, and civil construction industries, due to their strategic place in the country's economy and the number of workers they employ.

In the case of Petrobras, from 1995 to 2013, 320 workers suffered fatal accidents, of whom 268 (84\%) were outsourced workers and 52 (16\%) were company employees. Mathematically, considering that the ratio of outsourced workers to company employees was 4 to 1 , one could argue that the difference is explained by the number of outsourced workers $(360,180)$ compared to that of company employees $(86,108)$, i.e., there would logically be more accidents in outsourced workers. However, the mean annual fatal accident rate for 2000-2013 based on data systematized by Coutinho 7 shows that for outsourced workers the rate was 8.6 per 100,000 , while for company employees it was 5.6 per 100,000 , i.e., $50 \%$ higher among outsourced workers. The rate varied con- 
siderably over this 14-year period but was consistently higher among outsourced workers.

The reasons for this higher accident rate in outsourced workers in the petroleum industry have been shown by various qualitative studies on outsourcing and working conditions, revealing a higher incidence of lack of accident prevention measures, excessive work hours, and greater exposure to risks, with constant transferal of hazardous operations to outsourced workers (blatant outsourcing of risks), in addition absence of adequate training and qualification in a context in which the number of outsourced workers grew sevenfold, from 49,217 in 2000 to 360,180 in 2013.

Outsourcing in Brazil's electricity sector has been classified as one of the most hazardous, in the sense of placing workers' lives at risk, due both to the technical nature of the highly hazardous work process and the industry's restructuring, mainly through privatizations. It is also the sector with the best database on the electric power system, because it includes the workforce count for all the country's electricity companies, including both company employees and outsourced workers.

The COGE Foundation, a technical and scientific institution created in 1998 that conducts research on the Brazilian electricity sector, covering 67 public and private companies, provides work accident statistics for all categories of workers. The statistics calculated by the Foundation show the workforce trends for company employees and outsourced workers and fatal accidents, indicating and proving the inseparability of outsourcing and health precarization. As in the case of the petroleum industry, the number of fatal accidents in outsourced workers in the electricity sector has been higher every year from 2003 to 2012 .

The number of outsourced workers increased from 36,649 in 2003 to 146,314 (a growth of 299\%, or fourfold in 10 years), while the number of company employees increased from 97,399 to 108,133 , or only $11 \%$. In 2012 , outsourced workers represented $58 \%$ of the workforce in Brazil's national electricity system. In the same period, $87 \%$ of the fatal accidents occurred in outsourced workers, a much higher proportion than outsourced workers' share of the total workforce. Considering the annual mortality rates for each major group of workers shows the following: 12.0 fatal accidents per 100,000 company employees and 67.4 per 100,000 in outsourced workers, or 5.6 times more.

These irrefutable data prove the higher work accident mortality of outsourced workers compared to company employees. The causes of these deaths lie in working conditions, non- compliance with labor standards for prevention in health and safety, lack of training, insufficient qualification, lack of knowledge and experience in the work process (especially in power lines), lack of retraining, failure to provide personal protective equipment (PPE) or collective protective equipment (CPE), absent or malfunctioning CIPA as attested by the individual and class action suits filed by the Office of the Public Prosecutor for Labor and tried by the Labor Courts and in inspections conducted by labor auditors 7 .

It is widespread knowledge that civil construction ranks first in work accidents, explained by construction companies' noncompliance with workplace health and safety standards. The construction industry is also known to rely traditionally on outsourcing, with contracting networks and workforce intermediation using the "straw cat" system, a term borrowed from farm labor. The large construction companies have claimed the intermittent nature of their construction projects as the justification for contracting out, or turning to total flexibility in hiring small companies for predefined time periods.

However, both private construction projects and public works are known for their nonstop activity, only altering more or less according to fluctuations in the real estate market, which also applies to any branch of economic activity. Civil construction shows the highest workforce turnover of all industrial activities. More recently, contracting out has radicalized the use of national and international chains, where labor inspection has repeatedly found workers in conditions analogous to slave labor, as discussed by Filgueiras 13 .

A study that cross-analyzed the number of CATs issued in Brazil in 2013 with data on formal employment from the Brazilian Institute of Geography and Statistics (IBGE) reached a common denominator, the National Classification of Economic Activities (CNAE), and showed the following panorama with the overall construction industry for different subsectors or CNAEs: (1) construction of highways, railways, unspecified construction works, streets, squares, and sidewalks showed 4.55 times more fatal work accidents when compared to all economic sectors; (2) construction for generation and distribution of energy, telecommunications, water systems, sewage systems, industrial installations, and metallic structures generated 4.92 times more deaths; (3) demolition and earthmoving generated 3.3 times more fatal accidents in formally employed workers than the average for the overall labor market 6 .

For an analysis of outsourced workers in selected CNAEs in the construction industry, data 
were gathered on the number of deaths in 2013 and the number of outsourced workers that died in the set of subsectors, with the following results: finishing work showed 2.32 more fatal work accidents compared to the formal market as a whole. Twenty workers died, of whom 18 were outsourced workers. Earthmoving showed 3.3 times higher odds of dying than in the labor market as a whole; of the 19 deaths, 18 were outsourced workers. In unspecified specialized services and foundation construction, 30 outsourced workers and 4 company employees died, and the sector had 2.45 times higher mortality when compared to formal employees in the economy as a whole 6 .

The vulnerability of outsourced workers in civil construction received widespread media coverage with 12 deaths in the construction or renovation of soccer stadiums for the FIFA World Cup hosted by Brazil in 2014. Of the 12 fatal accidents, 11 were outsourced workers.

\section{Final remarks}

This summary of outsourcing status in Brazil when the country is redefining its legal framework (represented by Bill 4,330) clearly demonstrates the inseparability of outsourcing and precarization of work in all its dimensions, especially workers' health.

\section{References}

1. Ministério do Trabalho; Programa das Nações Unidas para o Desenvolvimento; Universidade Federal da Bahia. Relatório sobre terceirização e relações de trabalho nas empresas do Complexo Petroquímico de Camaçari. Subprojeto: o processo de terceirização e suas consequências sobre as condições de trabalho e saúde dos trabalhadores. Salvador: Delegacia Regional do Trabalho, Ministério do Trabalho/Programa das Nações Unidas para o Desenvolvimento/Centro de Recursos Humanos, Universidade Federal da Bahia; 1993.

2. Druck G. Terceirização e ajuste fiscal: uma dupla ofensiva contra os direitos do trabalho. Jornal dos Economistas 2015; (311):9-11. http://tinyurl.com/ otnklxs.

3. Franco T, Druck G. O trabalho contemporâneo no Brasil: terceirização e precarização. Salvador: Fundação Jorge Duprat Figueiredo de Segurança e Medicina do Trabalho; 2009.
The economic, social, and political vulnerability of outsourced workers, systematically revealed by studies in Brazil, is undeniable, shaping a condition of increased subordination to the despotism of capital, which seeks unceasingly to eliminate any restraint on this form of labor exploitation. Transferring liability for workers' safety to third parties and leaving the service companies as the central object of investigation and punishment by government are a way of covering up for the service buyers, the main culprits in the brutal precarization of work and health for millions of Brazilian workers. Relaxation of outsourcing is promoted in the core companies' name, neutralizing the forces that could effectively ensure limits, namely government and workers' trade union organizations.

Allowing outsourcing in Brazil means to legalize and legitimize predatory workforce exploitation in its cruelest form, disregarding workers' physical limits, exposing them to the risk of fatal work accidents, and backsliding to past forms of labor that violate the human condition.

In the case of work accidents, outsourcing of risks and responsibilities amplifies the propensity to accidents while creating invisibility for workers that have suffered accidents, who only become less invisible through action and complaints lodged by trade unions, labor law institutions, and academic researchers. Such action has become increasingly necessary to defend the lives of millions of Brazilian workers.

4. Druck G. Trabalho, precarização e resistências: no vos e velhos desafios. Caderno CRH 2011; 24:3757

5. Delgado GN, Amorim HS. Os limites constitucionais da terceirização. São Paulo: LTR; 2014.

6. Druck G, Filgueiras V. Epidemia da terceirização e a responsabilidade do STF. Revista do TST 2014; 80:106-25.

7. Coutinho G. Terceirização - máquina de moer gente trabalhadora: a inexorável relação entre a nova marchandage e a degradação ambiental, as mortes e mutilações no trabalho. São Paulo: LTR; 2015.

8. Fundação COGE. Relatório de estatísticas de acidentes de trabalho no setor elétrico brasileiro. ht tp://www.relatorio.funcoge.com.br/2013/index. html (accessed on 01/Jun/2015). 
9. Sanches AT. Terceirização e ação sindical no setor financeiro. In: Anais do XI Encontro Nacional da Associação Brasileira de Estudos do Trabalho. Campinas: Associação Brasileira de Estudos do Trabalho; 2009.

10. Central Única dos Trabalhadores. Terceirização e desenvolvimento: uma conta que não fecha. Dossiê sobre o impacto da terceirização sobre os trabalhadores e propostas para garantir a igualdade de direitos. São Paulo: Central Única dos Trabalhadores/Secretaria Nacional de Relações de Trabalho/Departamento Intersindical de Estatística e Estudos Socioeconômicos; 2014.

\section{Resumo}

O artigo apresenta uma discussão sobre o quadro da terceirização hoje no Brasil, quando está em curso uma nova regulamentação por meio de um Projeto de Lei em tramitação no Congresso Nacional, que tem por objetivo liberar a terceirização para todas as atividades. Argumenta sobre a indissociabilidade entre terceirização e precarização do trabalho, com base numa sistematização de resultados de 20 anos de pesquisas no Brasil, apresentando indicadores que comprovam as condições de trabalho mais precárias dos terceirizados para diversas categorias profissionais, destacadamente para o campo da saúde do trabalhador, em que a terceirização dos riscos tem levado a um número crescente de acidentes de trabalho com vítimas fatais que têm sido invariavelmente maiores entre os trabalhadores terceirizados. Por fim, avalia que liberar a terceirização no Brasil é legalizar e legitimar o uso predatório da força de trabalho na sua forma mais aguda, desrespeitando os limites físicos dos trabalhadores, expondo-os a riscos de morte e retornando a formas pretéritas de trabalho que transgridem a condição humana.

Serviços Terceirizados; Condições de Trabalho; Saúde do Trabalhador
11. Souza E. A "maquiagem" do trabalho formal: um estudo do trabalho das mulheres terceirizadas no setor de limpeza na Universidade Federal da Bahia [Doctoral Dissertation]. Salvador: Universidade Federal da Bahia; 2012.

12. Druck G, Franco T. A perda da razão social do trabalho: terceirização e precarização. São Paulo: Boitempo; 2007.

13. Filgueiras V. Terceirização e trabalho análogo ao escravo: coincidência? http://indicadoresderegu lacaodoemprego.blogspot.com.br (accessed on Jun/2014).

\section{Resumen}

El artículo presenta una discusión sobre el cuadro de la tercerización hoy en Brasil, cuando está en curso una nueva regulación, a través de un Proyecto de Ley en trámite en el Congreso Nacional, que tiene por objetivo liberar la tercerización para todas las actividades. Discute sobre la indisociabilidad entre tercerización y precarización del trabajo, en base a una sistematización de resultados de 20 años de investigaciones en Brasil, presentando indicadores que comprueban las condiciones de trabajo más precarias de los tercerizados para diversas categorías profesionales, destacando el campo de la salud del trabajador, donde la tercerización de los riesgos ha llevado a un número creciente de accidentes de trabajo con víctimas fatales, que han sido invariablemente mayor entre los trabajadores tercerizados. Por fin, evalúa que liberar la tercerización en Brasil es legalizar y legitimar el uso depredatorio de la fuerza de trabajo en su forma más aguda, sin respetar los límites físicos de los trabajadores, exponiéndoles a riesgos de muerte y retornando a formas pretéritas de trabajo que transgreden la condición humana.

Servicios Externos; Condiciones de Trabajo; Salud Laboral 